\title{
Identification of upstream miRNAs of SNAI2 and their influence on the metastasis of gastrointestinal stromal tumors
}

Jie Ding ${ }^{1 *+}\left(\mathbb{0}\right.$, Yu Xia ${ }^{2 \dagger}$, Zhaoyan Yu ${ }^{1}$, Jing Wen ${ }^{3}$, Zhuxue Zhang ${ }^{3}$, Zhongmin Zhang ${ }^{1}$, Zhenhua Liu', Zhuan Jiang ${ }^{1}$, Hang Liu' ${ }^{1}$ and Guoqing Liao ${ }^{4}$

\begin{abstract}
Background: SNAI2, a member of the snail zinc finger protein family, plays an important role in the metastasis of several types of carcinoma.

Objective: This study aims to investigate the upstream miRNAs of SNAI2 and their influence on the metastasis of gastrointestinal stromal tumors (GISTS).

Methods: The expression levels of SNAI2, CDH1, and CDH2 in GISTs were determined by immunohistochemistry, and the correlations with their clinicopathologic characteristics were analyzed. Subsequently, the miRNAs involved in regulating SNAI2 expression were predicted by bioinformatics technique, screened by miRNA microarray tests, and verified by real-time PCR, dual luciferase reporter assay, and invasion assay. The influence of SNAI2 and miRNAs on the invasive ability of the GIST cells and the related mechanism were detected.
\end{abstract}

Outcomes: SNAI2 expression significantly increased and $\mathrm{CDH} 1$ expression markedly decreased in the cases of GISTs with distant metastasis. Silencing of the SNAI2 gene impaired the invasiveness of GIST cells in vitro. MiR-200b-3p, miR30c-1-3P, and miR-363-3P were verified as the upstream metastasis-associated miRNAs of SNAI2 in GISTs by miRNA microarray, real-time PCR, dual luciferase reporter assay, and invasion assay. They bound to the 3'-UTR of SNAI2, downregulated SNAI2 expression, and inhibited the invasiveness of GIST cells. SNAI2 targetedly bound to the promoter of the $\mathrm{CDH1}$ gene, downregulated the expression of $\mathrm{CDH1}$, and contributed to the metastasis of GISTS.

Conclusion: SNAI2 and CDH1 correlated with the metastasis of GISTs, and silencing of the SNAI2 gene impaired the invasiveness of GIST cells. MiR-200b-3p, miR-30c-1-3P, and miR-363-3P contribute to the metastasis of GISTs in vitro by mediating the SNAI2/CDH1 axis. SNAI2 may be a potential target for the treatment of GISTs in the future.

Keywords: SNAI2, miRNA, Gastrointestinal stromal tumor, Metastasis

\section{Background}

Gastrointestinal stromal tumors (GISTs) are the most common mesenchymal malignancies in the digestive tract [1], and over $90 \%$ of GISTs are derived from c-Kit and PDGFRA gene mutations [2,3]. GISTs were first described by Mazur and Clark [4].The independent

\footnotetext{
*Correspondence: dingjieboy@126.com

${ }^{\dagger}$ Jie Ding and Yu Xia authors contribute equally to this work

1 Department of Gastrointestinal Surgery, Guizhou Provincial People's

Hospital, 83 East Zhongshan Rd, Guiyang 550002, Guizhou, China

Full list of author information is available at the end of the article
}

division of GISTs has exerted a considerable influence on their diagnosis and treatment. Although the integration of surgery and molecular-targeted therapy significantly improved the therapeutic effect of GISTs, more than $30 \%$ of the patients relapsed within 5 years and eventually died from this disease $[5,6]$.To date, the molecular mechanisms underlying GIST metastasis remain to be elucidated.

SNAI2, a member of the snail zinc finger protein family, binds to E-box motifs, represses CDH1 transcription, and contributes to the metastasis of various [7-10]. The transcriptional factor SNAI2 correlates closely with the 
metastasis of GISTs [11], and silencing of the SNAI2 gene impairs the invasiveness of GIST cells in vitro. However, the mechanism by which SNAI2 regulates the metastasis of GISTs remains unclear. In malignant tumors of epithelial origin, SNAI2 promotes tumor cell metastasis through epithelial-mesenchymal transition (EMT) [1216]. Lysine-specific demethylase 1 (LSD1) is essential in SNAI2-mediated transcriptional inhibition during EMT; in the absence of LSD1, SNAI2 fails to repress CDH-1 transcription [17]. SNAI2 is not specific for malignant tumors of epithelial origin; it also contributes to the metastasis of tumors of mesenchymal origin, such as osteosarcoma [18], chondrosarcoma [19], Ewing sarcoma [20], leiomyosarcoma [21], rhabdomyosarcoma [22], synovial sarcomas [23], GISTs [11], fibrosarcoma [24], and even Kaposi sarcoma [25, 26].

MicroRNA (MiRNA), an endogenous non-encoded RNA with a length of about 19-25 nucleotides, can interact with its targets in the $3^{\prime}$-UTR of transcripts and result in either mRNA degradation or translation inhibition in a sequence-dependent manner [27-30]. MiRNAs may be an effective molecular biomarker for tumor diagnosis and treatment [31]. MiRNAs could directly target genes and play a central role in EMT, modulating the metastatic process [32, 33]. Many miRNAs target SNAI2 and regulate the metastasis of cancer [34-36]. However, the miRNAs targeting the expression of SNAI2 in GISTs remain undetermined. In the present study, we identified the miRNAs that regulate SNAI2 expression and investigates the molecular mechanisms by which they influence GIST metastasis. Furthermore, we assessed the feasibility of using exogenous miRNAs to inhibit the invasion and metastasis of GIST cells. This study could serve as a basis for developing novel treatments for GISTs.

\section{Methods}

\section{Patients and specimens}

The archival formaldehyde-fixed and paraffin-embedded tumor tissue of 78 GIST specimens surgically removed from 2004 to 2007 were retrieved from the Department of Pathology, Xiangya Hospital, Central South University. No new adjuvant therapy was administered before surgery. Patient age ranged from 28 to 87 years old (median 51 ), and 48 were male and 30 were female. The primary tumor sites of the GIST specimens include the stomach $(n=47)$, small intestine $(n=26)$, and colorectum $(n=5)$. In accordance with the modified NIH consensus criteria

Table 1 Correlation between expression of SNAI2, E-cadherin, N-cadherin and clinicopathological characteristics of GIST patients

\begin{tabular}{|c|c|c|c|c|c|c|c|c|c|c|c|c|c|}
\hline \multirow[t]{2}{*}{ Item } & \multirow[t]{2}{*}{$n$} & \multicolumn{2}{|c|}{ SNAI2 (+) } & \multirow[t]{2}{*}{$x^{2}$} & \multirow[t]{2}{*}{$P$ value } & \multicolumn{2}{|c|}{ E-cad (+) } & \multirow[t]{2}{*}{$x^{2}$} & \multirow[t]{2}{*}{$P$ value } & \multicolumn{2}{|c|}{$\mathrm{N}-\operatorname{cad}(+)$} & \multirow[t]{2}{*}{$x^{2}$} & \multirow[t]{2}{*}{$P$ value } \\
\hline & & $\mathrm{n}$ & $\%$ & & & $\mathrm{n}$ & $\%$ & & & $\mathbf{n}$ & $\%$ & & \\
\hline \multicolumn{14}{|l|}{ Gender } \\
\hline Male & 48 & 28 & 58.3 & & & 21 & 43.8 & & & 39 & 81.3 & & \\
\hline Female & 30 & 14 & 46.7 & 1.01 & 0.32 & 7 & 23.3 & 3.34 & 0.07 & 20 & 66.7 & 2.13 & 0.14 \\
\hline \multicolumn{14}{|l|}{ Age } \\
\hline$<50$ years & 40 & 24 & 60.0 & & & 13 & 32.5 & & & 29 & 72.5 & & \\
\hline > 50 years & 38 & 18 & 47.4 & 1.25 & 0.26 & 15 & 39.5 & 0.41 & 0.52 & 30 & 78.9 & 0.44 & 0.51 \\
\hline \multicolumn{14}{|l|}{ Position } \\
\hline Stomach & 47 & 24 & 51.1 & & & 15 & 31.9 & & & 35 & 74.5 & & \\
\hline Intestine & 26 & 15 & 57.7 & & & 10 & 38.5 & & & 21 & 80.8 & & \\
\hline Colorectum & 5 & 3 & 60 & 0.38 & 0.83 & 3 & 60 & 1.66 & 0.44 & 3 & 60 & 1.07 & 0.59 \\
\hline \multicolumn{14}{|l|}{ Risk category } \\
\hline Very low & 5 & 2 & 40 & & & 2 & 40 & & & 4 & 80.0 & & \\
\hline Low & 20 & 11 & 55 & & & 9 & 45 & & & 16 & 80.0 & & \\
\hline Mid & 22 & 9 & 40.9 & & & 9 & 40.9 & & & 14 & 63.6 & & \\
\hline High & 31 & 20 & 64.5 & 3.30 & 0.348 & 8 & 25.8 & 2.37 & 0.50 & 25 & 80.6 & 2.4 & 0.49 \\
\hline \multicolumn{14}{|l|}{ Local invasion } \\
\hline Yes & 41 & 25 & 61 & & & 16 & 39.0 & & & 29 & 70.7 & & \\
\hline No & 37 & 17 & 45.9 & 1.77 & 0.18 & 12 & 32.4 & 0.37 & 0.54 & 30 & 81.1 & 1.13 & 0.29 \\
\hline \multicolumn{14}{|c|}{ Distant metastasis } \\
\hline Yes & 24 & 18 & 75 & & & 4 & 16.7 & & & 20 & 83.3 & & \\
\hline No & 54 & 24 & 4.4 & 6.24 & 0.01 & 24 & 44.4 & 5.57 & 0.02 & 39 & 72.2 & 1.11 & 0.29 \\
\hline
\end{tabular}


[37], 5 very-low-risk, 20 low-risk, 22 intermediate-risk, and 31 high-risk cases were identified (Table 1). This research was conducted with the approval of the ethics committee of Guizhou Provincial People's Hospital, China, and the ethics committee of Xiangya Hospital, Central South University. Documented informed consents were obtained from all patients.

\section{Cell lines and cell culture}

Both GIST882 and GIST-T1 were established from untreated human metastatic GISTs. GIST882 harbors a homozygous exon 13 missense mutation [38], and GIST-T1 has a heterogenic 57-bp deletion in exon 11 to produce a mutated c-KIT [39]. GIST882 cells were maintained in RPMI1640 supplemented with 10\% fetal bovine serum (FBS), and GIST-T1 cells were cultured in Dulbecco's modified Eagle's medium supplemented with $10 \%$ FBS. GIST cells were grown in cell culture flasks at $37^{\circ} \mathrm{C}$ in a humidified atmosphere of $95 \%$ air and $5 \% \mathrm{CO}_{2}$.

\section{miRNA target prediction}

Targetscan v7.1 was used to predict miRNA target.

\section{miRNAs microarray}

Human microRNA microarrays (HmiOA7.0, PhalanxBio Inc.) were used in GIST samples. The microarray contains probes for 2003 human microRNAs from Sanger miRBase release 19.0. Total RNA (100 ng) derived from GIST samples was labelled with Cy5 or Cy3. Microarray slides were scanned by DNA Microarray Scanner G2565B (Agilent Technology). Labeling and hybridization were performed in accordance with the protocols in the PhalanxBio miRNA microarray system. The microarray image information was converted into spot intensity values using Feature Extraction Software. The signal after background subtraction was exported directly into the GeneSpring GX10 software (Agilent Technologies, Santa Clara, CA).

\section{Transient transfection of miRNA mimics and inhibitors}

GIST cells $\left(5 \times 10^{4}\right)$ were seeded in 24 -well plates $24 \mathrm{~h}$ before transfection. The medium was replaced with antibiotics-free media $6 \mathrm{~h}$ before transfection. Selected miRNA mimics, inhibitors, and a negative control (from Sigma-Aldrich) were transfected into GIST cells using Lipofectamine $^{\mathrm{TM}} 3000$ following the Sigma-Aldrich transfection protocol. After $24 \mathrm{~h}$, the cells were split into two 24-well plates in antibiotics-containing media and cultured for an additional $48 \mathrm{~h}$. The cells were then washed twice with PBS and lysed in TRIzol reagent (Invitrogen). The sequences of the miRNA mimics and inhibitors used in this study are as follows:

\begin{tabular}{ll}
\hline miRNA & Sense $\left(\mathbf{5}^{\prime} \mathbf{-} \mathbf{3}^{\prime} \mathbf{)}\right.$ \\
\hline miR-30c-1-3p mimics & CUGGGAGAGGGUUGUUUACUCC \\
miR-30c-1-3p inhibitors & GGAGUAAACAACCCUCUCCCAG \\
miR-363-3p mimics & AAUUGCACGGUAUCCAUCUGUA \\
miR-363-3p inhibitors & UACAGAUGGAUACCGUGCAAUU \\
mir-1-3p mimics & UGGAAUGUAAAGAAGUAUGUAU \\
mir-1-3p inhibitors & AUACAUACUUCUUUACAUUCCA \\
mir-375 mimics & UUUGUUCGUUCGGCUCGCGUGA \\
mir-375 inhibitors & UCACGCGAGCCGAACGAACAAA \\
mir-32-3p mimics & CAAUUUAGUGUGUGUGAUAUUU \\
mir-32-3p inhibitors & AAAUAUCACACACACUAAAUUG \\
Mimics NC & UUGUACUACACAAAAGUACUG \\
Inhibitor NC & CAGUACUUUUGUGUAGUACAA \\
\hline
\end{tabular}

\section{Transient transfection of siRNA or CDNA}

Cells $\left(5 \times 10^{4}\right)$ were seeded in 6 -well plates and then incubated for 2-4 days in standard medium in the presence of 10-20 nmol/L siRNA or cDNA directed against target genes. Cells were transfected using Lipofectamine 3000 (Invitrogen) in accordance with the manufacturer's instructions. Cells were transfected with a scrambled siRNA as a control and untreated cells as a blank control. After $24 \mathrm{~h}$, transfection efficiency was assessed as GFP fluorescence under a fluorescence microscope. Human SNAI2 cDNA was produced by PCR amplification of reverse-transcribed products of total RNA from GIST882 cells by using the specific primers, (F: $5^{\prime}$-ATG CCGCGCTCCTTCCTGGT-3'， R: 5'-TCAGTGTGC TACACAGCAGCC-3').

The siRNA sequences used in this study were as follows:

\begin{tabular}{|c|c|c|}
\hline siRNA & Sense $\left(5^{\prime}-3^{\prime}\right)$ & Antisense $\left(5^{\prime}-3^{\prime}\right)$ \\
\hline SNAI2 (\#1) & $\begin{array}{l}\text { CGUAUCUCUAUGAGA } \\
\text { GUUATT }\end{array}$ & $\begin{array}{l}\text { UAACUCUCAUAGAGA } \\
\text { UACGTT }\end{array}$ \\
\hline SNAI2 (\#2) & $\begin{array}{l}\text { CAUUCUGAUGUA } \\
\text { AAGAAAUTT }\end{array}$ & $\begin{array}{l}\text { AUUUCUUUACAUCAG } \\
\text { AAUGTT }\end{array}$ \\
\hline SNAI2 (\#3) & $\begin{array}{l}\text { CAUGGAAUUCAU } \\
\text { GUGUUUATT }\end{array}$ & $\begin{array}{l}\text { UAAACACAUGAAUUC } \\
\text { CAUGTT }\end{array}$ \\
\hline $\mathrm{CDH} 1(\# 1)$ & $\begin{array}{l}\text { CCUCGACACCCGAUU } \\
\text { CAAATT }\end{array}$ & $\begin{array}{l}\text { UUUGAAUCGGGUGUC } \\
\text { GAGGTT }\end{array}$ \\
\hline $\mathrm{CDH} 1(\# 2)$ & $\begin{array}{l}\text { CCGAUCAGAAUGACA } \\
\text { ACAATT }\end{array}$ & $\begin{array}{l}\text { UUGUUGUCAUUCUGA } \\
\text { UCGGTT }\end{array}$ \\
\hline $\mathrm{CDH} 1(\# 3)$ & $\begin{array}{l}\text { GGUUCAAGCUGC } \\
\text { UGACCUUTT }\end{array}$ & $\begin{array}{l}\text { AAGGUCAGCAGCUUG } \\
\text { AACCTT }\end{array}$ \\
\hline $\mathrm{CDH} 2(\# 1)$ & $\begin{array}{l}\text { GUGCAGUCUUAU } \\
\text { CGAAGGATT }\end{array}$ & $\begin{array}{l}\text { UCCUUCGAUAAGACU } \\
\text { GCACTT }\end{array}$ \\
\hline $\mathrm{CDH} 2(\# 2)$ & $\begin{array}{l}\text { AAGUACAAUAUGAGA } \\
\text { GCAGTT }\end{array}$ & $\begin{array}{l}\text { CUGCUCUCAUAUUGU } \\
\text { ACUUTT }\end{array}$ \\
\hline $\mathrm{CDH} 2(\# 3)$ & $\begin{array}{l}\text { UGGCAUGGUGUA } \\
\text { UGCCGUGTT }\end{array}$ & $\begin{array}{l}\text { CACGGCAUACACCAU } \\
\text { GCCATT }\end{array}$ \\
\hline Control siRNA & $\begin{array}{l}\text { UUCUCCGAACGU } \\
\text { GUCACGUTT }\end{array}$ & $\begin{array}{l}\text { ACGUGACACGUUCGG } \\
\text { AGAATT }\end{array}$ \\
\hline
\end{tabular}




\section{Immunohistochemical staining}

Primary antibodies were directed toward SNAI2 (rabbit monoclonal, 1:200; R\&D Systems, Minneapolis, MN, USA), CDH1 (rabbit polyclonal, 1:200; R\&D Systems), and CDH2 (rabbit polyclonal, 1:100; R\&D Systems). Serial sections of $5 \mu \mathrm{m}$ were cut from the tissue blocks, deparaffinized in xylene, and hydrated in a graded series of alcohol. Staining was then performed using the EnVision + anti-rabbit system (Dako Corporation, Carpinteria, CA, USA). Negative control staining was carried out by substituting nonimmune rabbit and phosphate-buffered saline for the primary antibodies.

\section{Evaluation of immunohistochemical staining results}

The evaluations were performed by two pathologists who were unaware of the patients' information. In cases of disagreement, another review and discussion was performed by both pathologists to obtain a consensus. The two-way scoring system of staining intensity and staining extent was used to analyze the immunohistochemical staining results. Staining intensity was graded as follows: negative (0), weak (1), moderate (2), and strong (3). Staining extent was rated according to the percentage of positive cells. Samples with no stained tumor cells were rated as 0 , those with $<25 \%$ of stained tumor cells as 1 , those with $25-50 \%$ as 2 , and those with $>50 \%$ as 3 . The results of staining intensity and extent produced an overall staining score. An overall score of 0 was marked as negative $(-), 1-2$ as weak $(+), 3-4$ as moderate $(++)$, and 5-6 as strong $(+++)$.

\section{Western blot}

Protein lysates were extracted from cells and blotted as described previously [40]. The membranes were incubated overnight using the following antibodies and dilutions: SNAI2, 1:1000; CDH-1, 1:2000; CDH2, 1:2000; and GAPDH, 1:2000.

\section{Real-time PCR}

The total RNA was extracted using Trizol reagent (Invitrogen, CA, USA). cDNA synthesis was generated using $1 \mu \mathrm{g}$ of total RNA with an iScript cDNA Synthesis Kit (Bio-Rad, CA, USA). The reaction mixture was initially denatured for $10 \mathrm{~min}$ at $95^{\circ} \mathrm{C}$, followed by 40 PCR cycles of a denaturing step $\left(95^{\circ} \mathrm{C}\right.$ for $\left.15 \mathrm{~s}\right)$ and a primer annealing/extension step $\left(60{ }^{\circ} \mathrm{C}\right.$ for $\left.60 \mathrm{~s}\right)$. The expression values were normalized to the geometric mean of GAPDH. The primers used in this study are as follows:

\begin{tabular}{|c|c|c|}
\hline miRNA & $F\left(5^{\prime}-3^{\prime}\right)$ & $R\left(5^{\prime}-3^{\prime}\right)$ \\
\hline hsa-miR-1-3p & $\begin{array}{l}\text { GGGTGGAATGTAAAG } \\
\text { AAGT }\end{array}$ & TTTGGCACTAGCACATT \\
\hline hsa-miR-375 & $\begin{array}{l}\text { GTTTTGTTCGTTCGG } \\
\text { CTC }\end{array}$ & TTTGGCACTAGCACATT \\
\hline hsa-miR-32-3p & $\begin{array}{l}\text { GGGCAATTTAGTGTG } \\
\text { TGTG }\end{array}$ & TTTGGCACTAGCACATT \\
\hline hsa-miR-30c-1-3p & $\begin{array}{l}\text { TTCTGGGAGAGG } \\
\text { GTTGT }\end{array}$ & TTTGGCACTAGCACATT \\
\hline hsa-miR-200c-3p & $\begin{array}{l}\text { GGTAATACTGCCGGG } \\
\text { TAAT }\end{array}$ & TTTGGCACTAGCACATT \\
\hline hsa-miR-200b-3p & $\begin{array}{l}\text { GGGTAATACTGCCTG } \\
\text { GTAA }\end{array}$ & TTTGGCACTAGCACATT \\
\hline hsa-miR-363-3p & $\begin{array}{l}\text { GGATTGCACGGT } \\
\text { ATCCA }\end{array}$ & TTTGGCACTAGCACATT \\
\hline hsa-miR-182-5p & $\begin{array}{l}\text { GGTTTGGCAATGGTA } \\
\text { GAACT }\end{array}$ & TTTGGCACTAGCACATT \\
\hline GAPDH & $\begin{array}{l}\text { TACTAGCGGTTTTAC } \\
\text { GGGCG }\end{array}$ & $\begin{array}{l}\text { TCGAACAGGAGGAGC } \\
\text { AGAGAGCGA }\end{array}$ \\
\hline
\end{tabular}

\section{ChIP}

Chromatin immunoprecipitation (ChIP) analysis was performed using Protein A and Protein G Dynabeads (Invitrogen) as previously reported [41]. Cells were exposed to $1 \%$ formaldehyde to crosslink proteins, and $1.0 \times 10^{7}$ cells were used for each ChIP assay. Quantitative ChIP was performed using qPCR on the ABI PRISM 7900 real-time PCR detection system (Applied Biosystems). Primer sequences for the qPCR of promoters of target genes for ChIP were as follows: CDH1,F: $5^{\prime}$-AGT CCCACAACAGCATAGGG-3', R: 5'-TTCTGAACT CAGGCGATCCT-3'; CDH2, F: 5'-GGGTAAGAACAA GCACTTCTGA-3', R: 5'-TACTGTTGCTGGCTAGGC TT-3'; GAPDH, F: 5'-TACTAGCGGTTTTACGGG CG-3', R: 5'-TCGAACAGGAGGAGCAGAGAGCGA $-3^{\prime}$. Sheared genomic DNA was used as a positive control (input) and for the normalization of DNA immunoprecipitated by SNAI2.

\section{Transwell invasion assay}

Invasion assays were performed by using BD BioCoat $^{\mathrm{TM}}$ Matrigel Invasion Chambers. In brief, cells in the log growth phase were trypsinized and suspended in serum-free media (with $0.04 \%$ BSA) at a density of $4 \times 10^{5}$ cells $/ \mathrm{mL}$. Designated control or treated suspended cells $(0.5 \mathrm{~mL})$ were added to each migration or invasion chamber and incubated at $37{ }^{\circ} \mathrm{C}$ for $22 \mathrm{~h}$. In addition, $25 \mathrm{ng} / \mathrm{mL}$ HGF $(0.75 \mathrm{~mL})$ was added to 
the lower well of each companion plate to attract cells from migration or invasion chamber plate inserts at the top of the companion plate. Cells that invaded or migrated the lower wells were then fixed and stained with $0.5 \%$ Toluidine Blue for $15 \mathrm{~min}$ at $37{ }^{\circ} \mathrm{C}$ and washed twice with TBS. The stained cells were counted under an inverted microscope (5 fields per membrane). All experiments were conducted at least three times in triplicate.

\section{Scratch wound-healing assay}

GIST cells were cultured until they reached $90 \%$ confluence in $25 \mathrm{~mm}$ dishes. Subsequently, scratches were generated using a sterile $20 \mu \mathrm{L}$ pipette tip prior to cells being treated with SNAI2 siRNA or NC siRNA for $48 \mathrm{~h}$. The border of the denuded area was immediately marked with a fine line, and cells were incubated in RPMI1640 supplemented with $10 \%$ FBS. Images of the cell cultures were captured at $48 \mathrm{~h}$ using an inverted phase contrast microscope. Assays were performed in triplicate.

\section{Luciferase reporter assay}

The 1130 nt SNAI2 3'-UTR (GenBank ID: NM_003068) was cloned into the multiple cloning site of the pGL3 dual-luciferase miRNA target expression vector (Promega, Madison, WI). SNAI2 was co-transfected with
$1 \mu \mathrm{g}$ of constructed plasmids and $100 \mathrm{nM}$ of miRNA mimics and the negative control using Lipofectamine ${ }^{\mathrm{TM}}$ 3000 (Invitrogen, Carlsbad, CA). Empty vector was used as a blank control. After $48 \mathrm{~h}$ of transfection, cells were harvested to measure luciferase activity using the Luciferase Assay System Kit (Promega, E1500) in accordance with the manufacturer's instructions.

\section{Statistical analysis}

Statistical analysis was performed using SPSS V.17.0 software. Differences in the expression levels of SNAI2, $\mathrm{CDH} 1$, and $\mathrm{CDH} 2$ among different clinicopathological characteristics were analyzed by $x^{2}$ test. All in vitro assays were repeated three times to provide biological replicates. Statistical comparisons were performed using two-tailed student's T-test or two-way ANOVA as appropriate. Statistical significance was considered at $\mathrm{P}<0.05$.

\section{Results}

SNAI2 correlated closely with the metastasis of GISTs, and silencing of the SNAI2 gene impaired the invasiveness of GIST cells in vitro

Seventy-eight GIST specimens removed by surgery from 2004 to 2007 were obtained in Xiangya Hospital, Central South University. The expression levels of SNAI2, CDH1, and $\mathrm{CDH} 2$ in the GISTs were determined by immunohistochemistry to determine whether the expression levels of SNAI2, CDH1, and CDH2 correlate with the
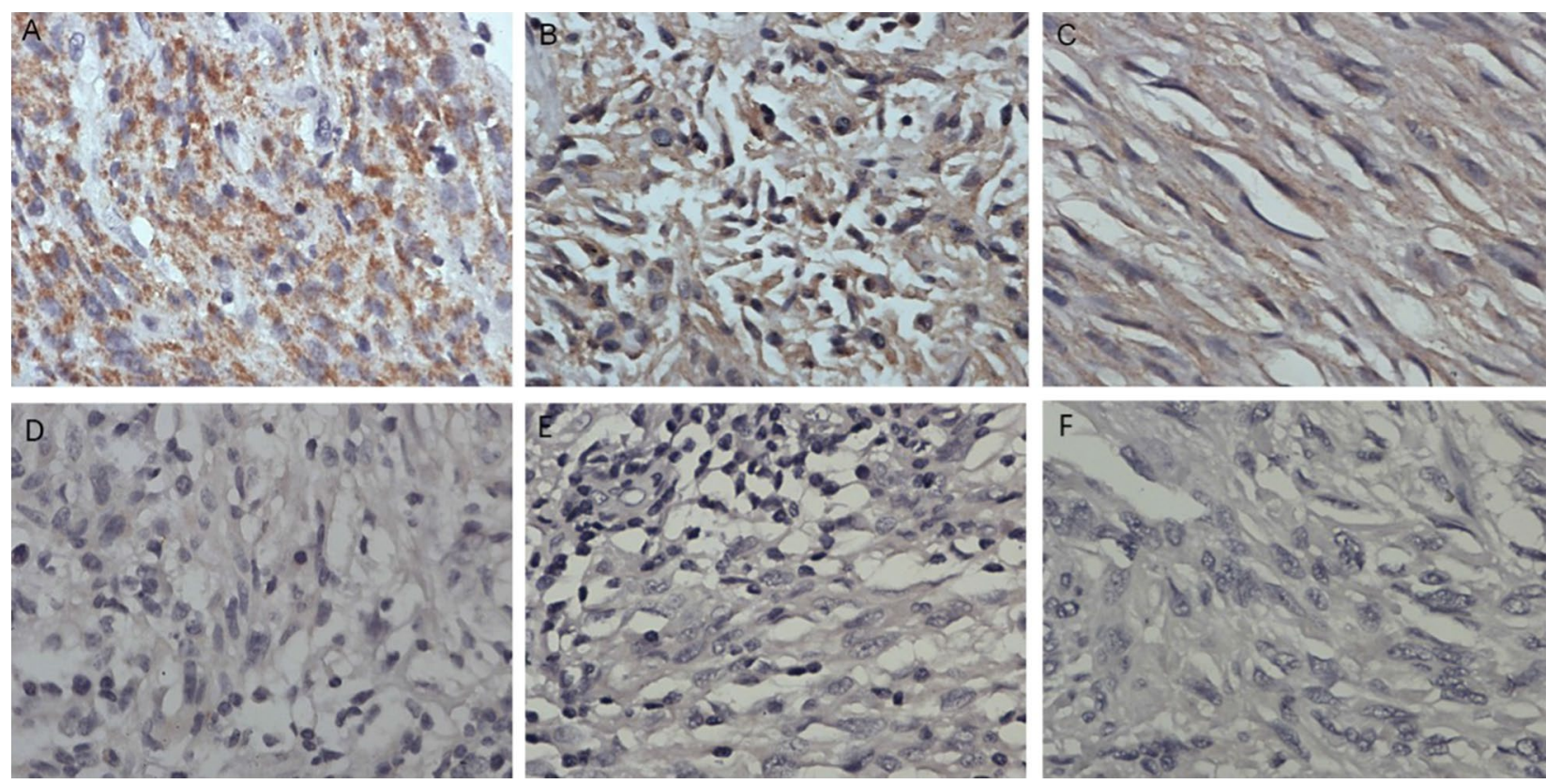

Fig. 1 Immumohistochemical staining of SNAI2, CDH1 and CDH2 staining in GIST specimens. (A, D) Representative positive and negative staining of SNAI2 in GISTs specimens. (B, E) Representative positive and negative staining of CDH1 in GISTs specimens. (C, F) Representative positive and negative staining of $\mathrm{CDH} 2$ in GISTs specimens. The positive expression of SNAI2, CDH1 and CD2 in GISTs were 53.8\%, 35.9\% and 75.6\% respectively 
clinicopathological characteristics of GIST patients. SNAI2 protein was mainly located in the cytoplasm of GIST cells, with a few cells showing localization in the nucleus. $\mathrm{CDH} 1$ and $\mathrm{CDH} 2$ proteins were localized in the cytomembrane and cytoplasm of GIST cells (Fig. 1). As shown in Table 1, the positive expression of SNAI2, CDH1, and CD2 in GISTs were 53.8\%, 35.9\%, and 75.6\%, respectively. SNAI2 expression significantly increased in the cases of GISTs with metastasis $(\mathrm{P}<0.05)$. CDH1 expression markedly decreased in the cases with distant metastasis $(\mathrm{P}<0.05)$. However, the expression of $\mathrm{CDH} 2$ did not significantly change among the different clinicopathological characteristics $(\mathrm{P}>0.05)$.

We conducted a SNAI2 gene silencing experiment to investigate the role of SNAI2 in the metastasis of GIST cells. First, three siRNAs targeting SNAI2 (siSNAI2\#1, siSNAI2\#2, and siSNAI2\#3) were transfected to GIST cells to detect gene-silencing efficiency. The knockdown effect of siSNAI2\#2 was better than that of the two other siRNAs at the mRNA and protein levels (Fig. 2). Using the siSNAI2\#2, we performed Transwell Invasion Assay and Scratch wound-healing assay in GIST cell lines and found a significant inhibition of invasion by siRNA (Fig. 2). However, the mechanism by which SNAI2 regulates the metastasis of GISTs remains unclear.

\section{Prediction and screening of the upstream metastasis-associated miRNAs of SNAI2 in GISTs}

Targetscan is a server for predicting the target genes of microRNAs (miRNAs). It was used to predict the upstream miRNAs of SNAI2. Results showed that 425 miRNAs may target SNAI2 (Additional file 1). Then, miRNA microarray was used to detect the differentially expressed miRNAs between three high-SNAI2-level GISTs (+++) and three low-SNAI2-level GISTs (-). Results showed that 339 miRNAs were upregulated and 85 miRNAs were downregulated in the high-SNAI2-level GISTs compared with the low-SNAI2-level GISTs (Additional file 2, Fig. 3).

The results of TargetScan and miRNA microarray were combined to evaluate the upstream miRNAs of SNAI2 in GISTs. Twelve miRNAs were selected as the possible upstream miRNAs of SNAI2. Among which, the following eight miRNAs were associated with cancer metastasis: miR-1-3p, miR-375, miR-32-3p, miR-200b-3p, miR-200c-3p, miR-30c-1-3p, miR-363-3p, and miR182-5p (Fig. 4).

\section{Confirmation of the upstream metastasis-associated miRNAs of SNAI2 in GISTs}

Real-time PCR was used to detect the levels of the eight possible metastasis-associated miRNAs in GISTs.
According to the principle of $\mathrm{L} / \mathrm{H} \geq 2$ (miRNA concentration in low SNAI2 level GISTs/miRNA concentration in high SNAI2 level GISTs), five miRNAs (miRNA-1-3P, miRNA-200b-3p, miRNA-32-3P, miRNA-30c-1-3P, and miRNA-363-3P) were selected as the candidate upstream miRNAs of SNAI2 (Fig. 4). Transfection of miRNA mimics and inhibitors was used to further confirm the upstream miRNAs of SNAI2. Results showed that three miRNAs, namely, miR-200b-3p, miR-30c-1-3P, and miR363-3P, could downregulate the SNAI2 transcription (Fig. 5). Then, Transwell invasion assay was used to detect the influence of miRNAs on the invasive ability of GIST cells. Interestingly, the invasiveness of the GIST cells was downregulated by miRNA mimics and upregulated by inhibitors of three miRNAs, namely, miR-200b-3p, miR30c-1-3P, and miR-363-3P (Fig. 6).

\section{MiR-200b-3p, miR-30c-1-3P, and miR-363-3P targetedly bind to the $3^{\prime}$-UTR of SNAI2 and downregulate SNAI2 expression}

Luciferase reporter assays were performed to detect the interaction of miRNAs and their targeting sequence in the 3'-UTR of SNAI2 mRNA. Five candidate miRNAs, Mimics NC were transfected into HEK293T cells that stably express a luciferase reporter containing the 3'-UTR of SNAI2 mRNA. As shown in Fig. 7, co-transfection of pGL3-SNAI2-3'-UTR and the miRNA mimics led to a downregulation of luciferase signal from 73 to $83 \%$ of that in the control group, which confirmed the direct binding of miR-200b-3p, miR-30c-1-3P, and miR363-3P to the SNAI2 $3^{\prime}$-UTR.

\section{Silencing SNAI2 led to the upregulation of $\mathrm{CDH} 1$ expression and downregulated the invasiveness of GIST cells}

SNAI2 acts as an inhibitory transcription factor that binds to E-box motifs of CDH1 and represses its transcription in cancer [9]. However, the mechanism by which SNAI2 affects the invasive ability of GIST cells is unclear. We performed a knockdown and overexpression experiment of SNAI2 to further investigate whether $\mathrm{CDH} 1$ and $\mathrm{CDH} 2$ are the downstream target genes of SNAI2 in GIST cells. At $48 \mathrm{~h}$ after transfection, the expression of CDH1 was upregulated in the SNAI2 knockdown group and downregulated in the SNAI2 overexpression group. However, the expression of CDH2 remained invariable (Fig. 8). Transwell Invasion Assay was used to investigate the invasiveness following the knockdown of CDH1 and CDH2 of GIST cells. Results showed that the invasive ability of the GIST cells were upregulated by $\mathrm{CDH} 1$ inhibition and downregulated by CDH2 inhibition (Fig. 9). 


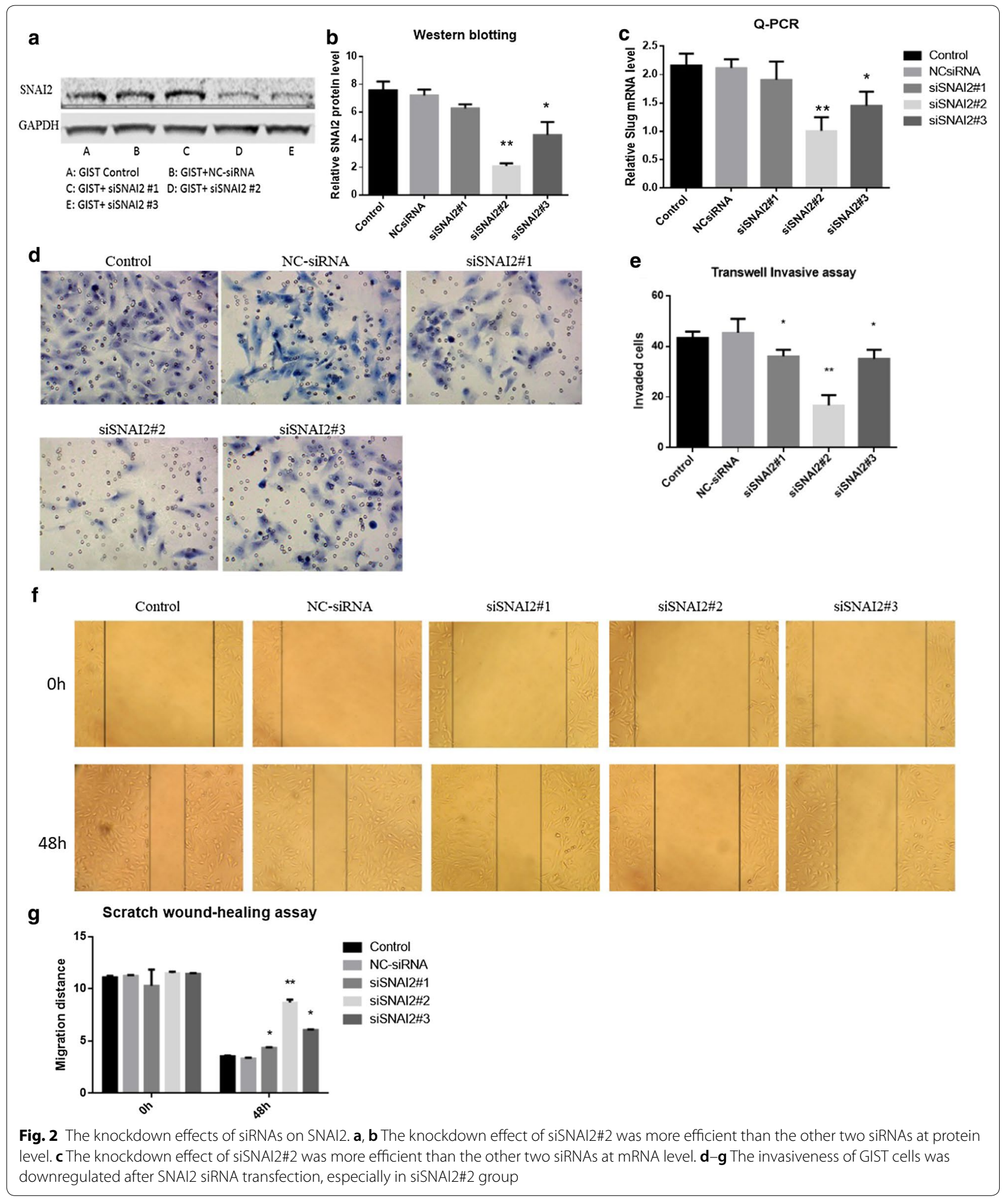




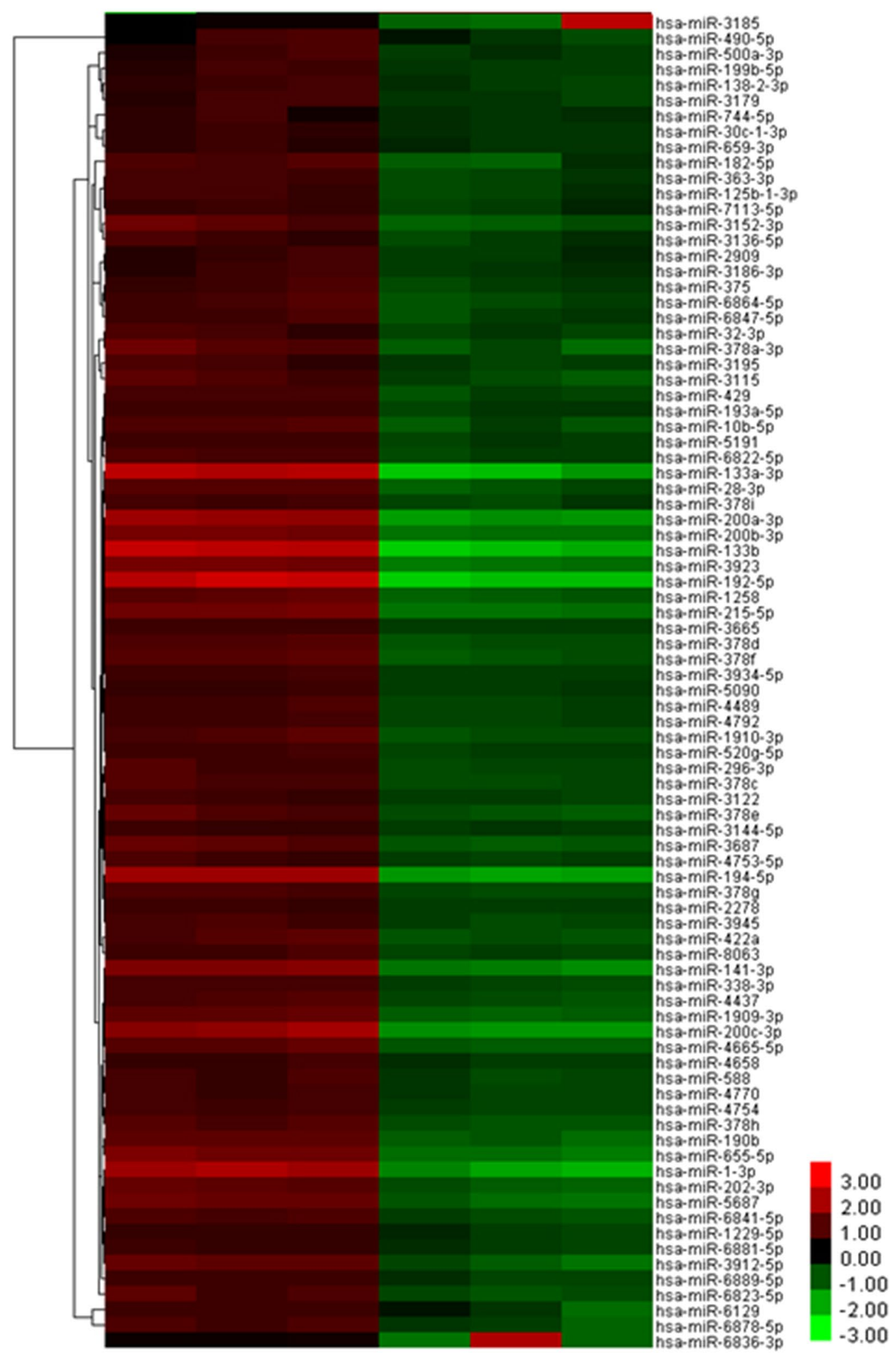

Fig. 3 Unsupervised hierarchical clustering analysis of miRNA expression profiles from GISTs specimen:85 miRNAs were downregulated in high SNAI2 level GISTs compared with low SNAI2 level GISTs 

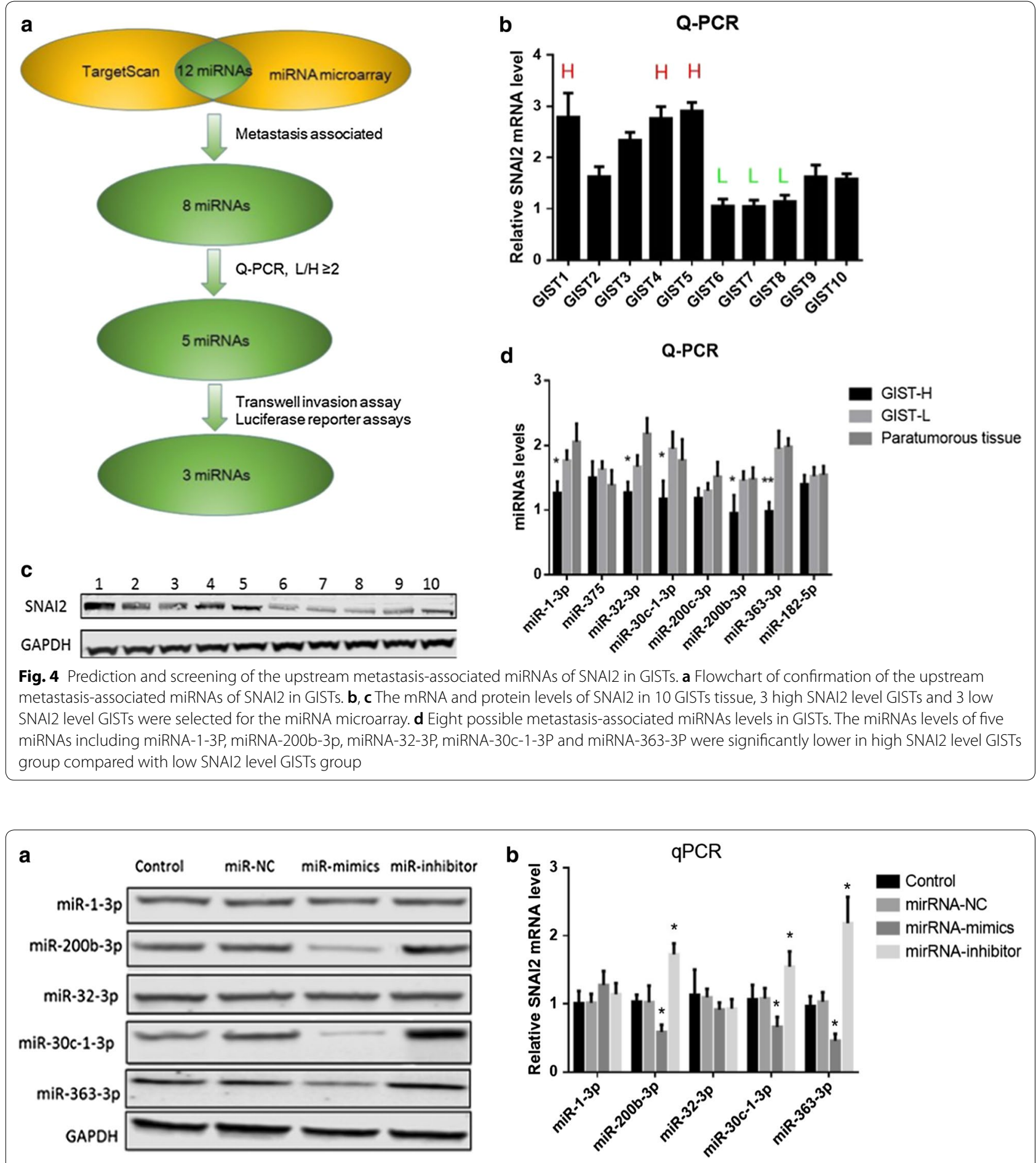

Fig. 5 SNAI2 levels after transfection of miRNA mimics and inhibitors. a, b MiR-200b-3p, miR-30c-1-3P and miR-363-3P could downregulate the SNAI2 in both protein and mRNA level 


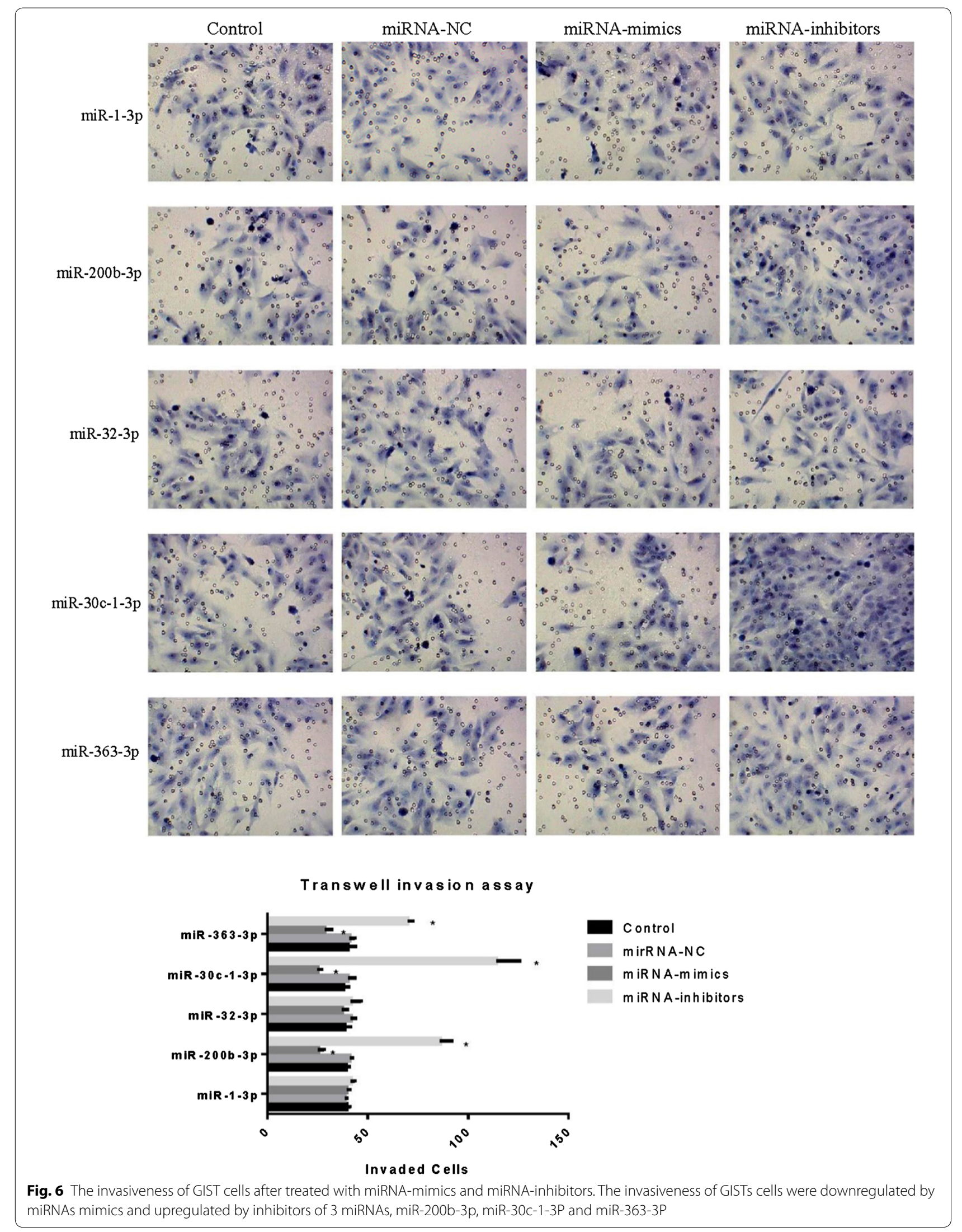




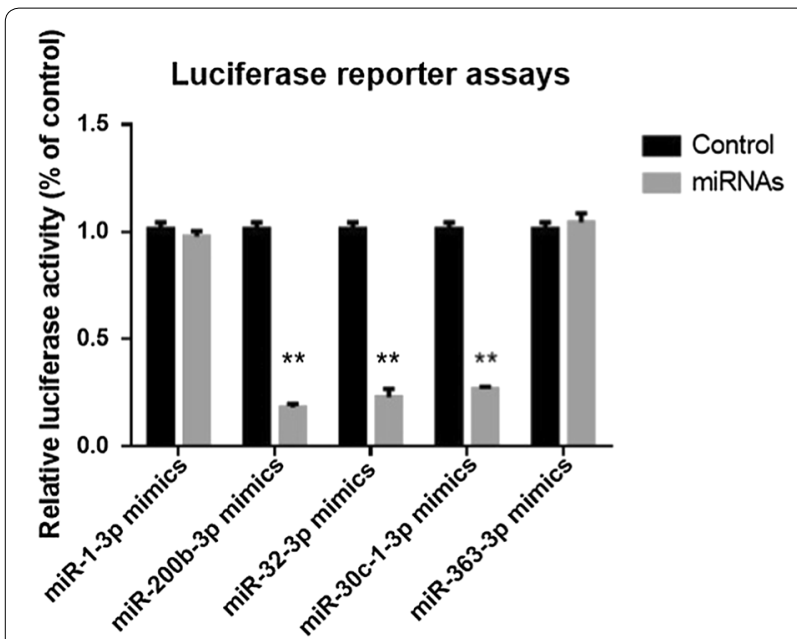

Fig. 7 Luciferase reporter assays. Transfection of miRNA mimics of miR-200b-3p, miR-30c-1-3P, miR-363-3P resulted in a decrease in luciferase signal to from 73 to $83 \%$ of that in the negative control

SNAI 2 targetedly binds to the promoter of the CDH1 gene, downregulates the expression of $\mathrm{CDH} 1$, and contributes to the metastasis of GISTs

Considering that knockout of SNAI2 was accompanied by the upregulation of $\mathrm{CDH}-1$, the inhibition of invasive ability of GIST cells, and the invariable expression of $\mathrm{CDH}-2$, we speculated that SNAI2 facilitates the metastasis of GISTs by inhibiting CDH-1 expression. ChIP analysis was performed to determine whether the promoters of CDH-1 and CDH-2 are directly regulated by SNAI2, which contributes to metastasis of GIST cells. Results confirmed that SNAI2 was present at the proximal promoter of CDH-1 but absent at that of CDH-2. Quantitative analysis revealed that the enrichment of SNAI2 at the proximal promoter of $\mathrm{CDH}-1$ significantly increased in the SNAI2 overexpression group and decreased in the SNAI2 knockdown group (Fig. 10). Therefore, we conclude that SNAI2 targetedly binds to the promoter of the $\mathrm{CDH} 1$ gene, downregulates the expression of $\mathrm{CDH} 1$, and consequently contributes to the metastasis of GISTs.

\section{Discussion}

GISTs are common mesenchymal malignancies in the digestive tract. Nearly $40 \%$ of GISTs that are localized at the time of detection give rise to metastases [1]. Although molecular targeted drugs and surgery have significantly improved the therapeutic effects of GISTs, more than $30 \%$ of patients with GISTs relapse within 5 years $[5,6]$. To date, the mechanism underlying GIST metastasis remains to be elucidated.

EMT contributes to carcinoma metastasis. SNAI2 is a prominent EMT-inducing transcription factor that facilitates tumor cell invasion, metastasis, and survival [7-10]. The regulation of tumor metastasis by SNAI2 is not only limited to epithelial-derived carcinomas but also interstitial tumors [18-26]. Yang et al. [21] found that the expression of CDH1 and SNAI2 negatively correlates in leiomyosarcoma. Silencing the SNAI2 gene could significantly upregulate the expression of CDH1, downregulate the expression of vimentin and $\mathrm{CDH} 2$ in leiomyosarcoma cells, and significantly impair the proliferation and invasiveness of cells. Our research also found that SNAI2 expression markedly increased and CDH1 expression markedly decreased in the GIST cases with distant metastasis. Silencing of the SNAI2 gene impaired the invasiveness of GIST cells in vitro, which demonstrated that both SNAI2 and CDH1 play an important role in GIST metastasis. This process is contrary to EMT where acquisition of a mesenchymal phenotype and loss of epithelial phenotype are associated with improved tumor cell invasiveness [42, 43]. Similarly, Pulkka et al. [44] found that SNAI2 downregulation inhibits cell proliferation, induces cell death, and increases the sensitivity of GIST cells to the treatment of imatinib mesylate. High expression of SNAI2 in

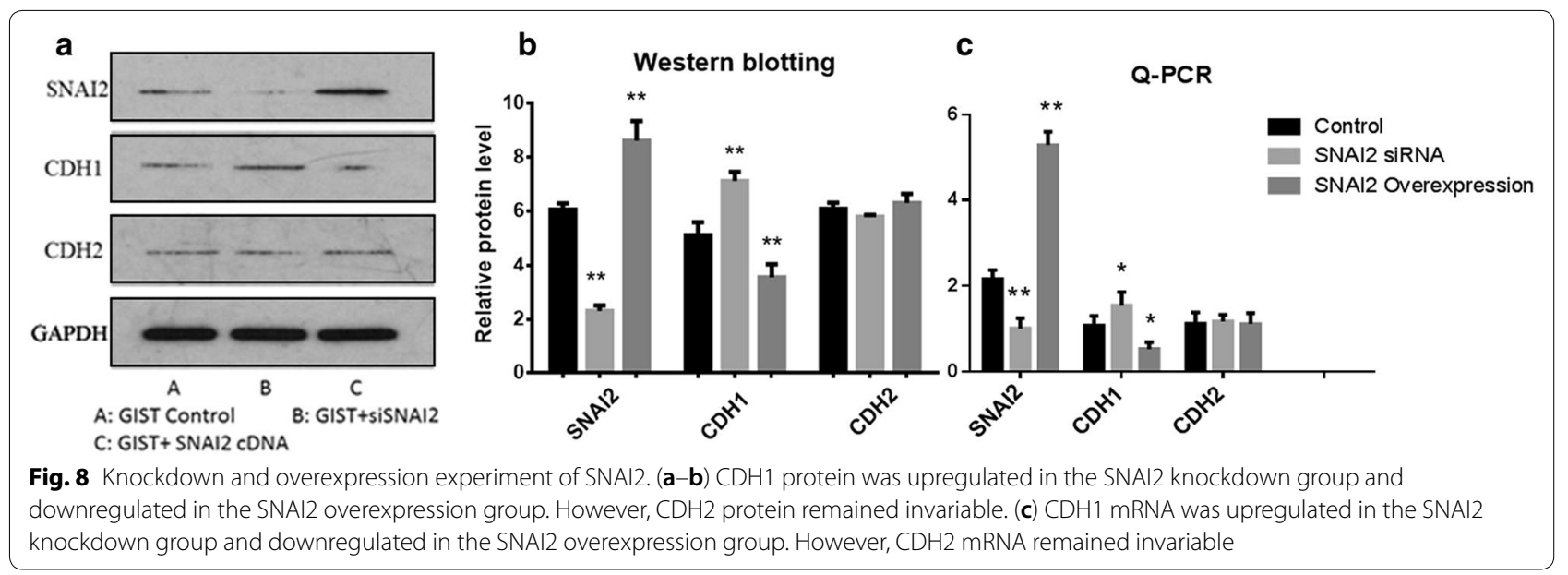



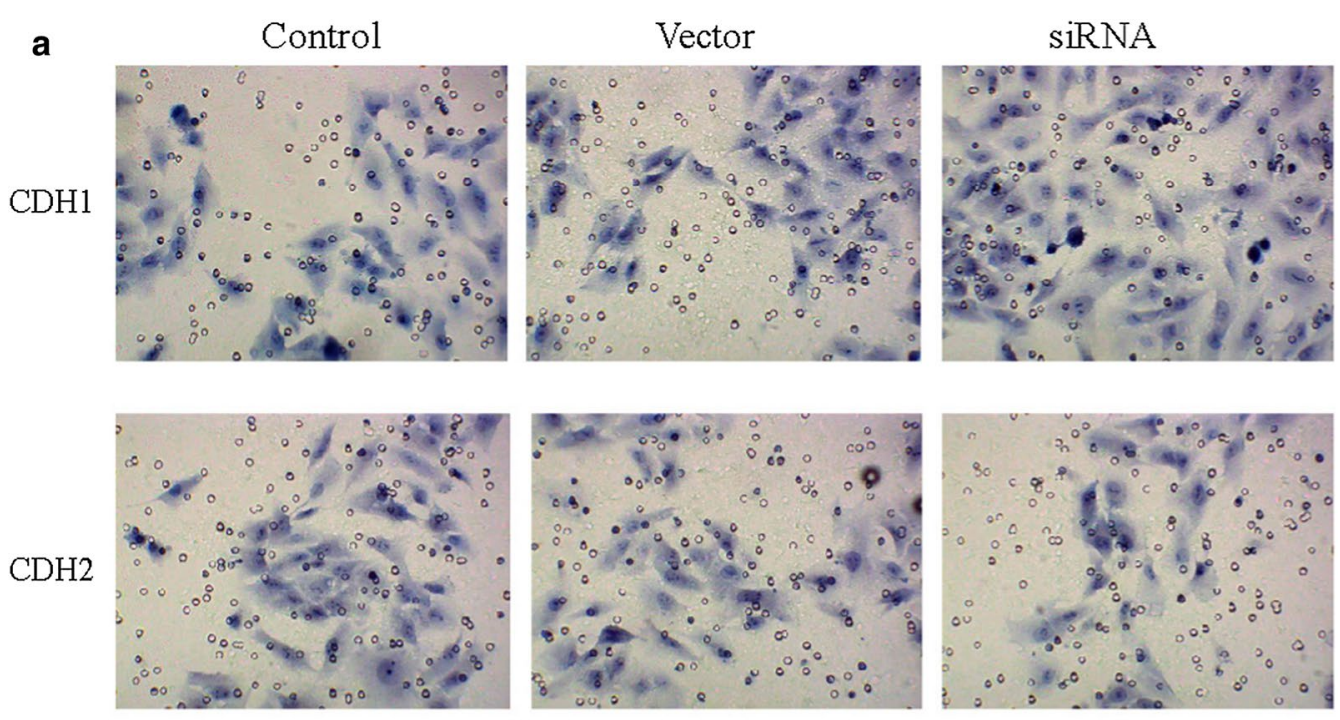

b

Transwell invasion assay

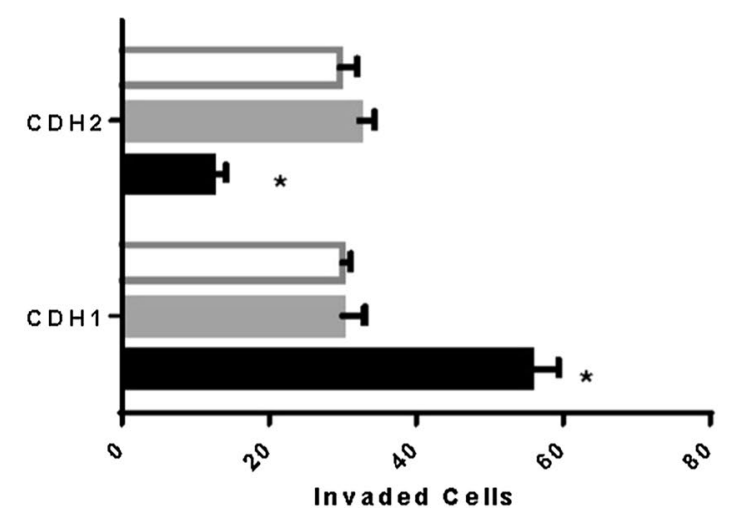

SIRNA

Vector

Control

Invaded Cells

Fig. 9 The invasiveness of GIST cells after knock down of $\mathrm{CDH} 1$ and $\mathrm{CDH} 2 . \mathbf{a}$, $\mathbf{b}$ The invasive ability of GIST cells was upregulated by $\mathrm{CDH} 1$ inhibition, and downregulated by $\mathrm{CDH} 2$ inhibition

GISTs indicates a worse prognosis, and they speculated that SNAI2 acts as a pro-proliferative factor in GISTs.

Our research revealed that SNAI2 protein targetedly bound to the promoter of the CDH1 gene, downregulated the expression of $\mathrm{CDH} 1$, and increased the invasiveness of GIST cells. SNAI2-induced inhibition of CDH1 is mediated by its binding to proximal E-boxes of the CDH1 promoter [45]. This effect is dependent on LSD1-mediated histone methylation modification $[46,47]$. The SNAG domain of SNAI2 functions as a molecular hook to recruit LSD1 to the promoters of its target gene, such as CDH1, decreases the monomethylation and dimethylation of histone $\mathrm{H} 3$ lysine4 (H3K4) at this region, downregulates gene expression, and consequently contributes to cancer metastasis $[47,48]$.

MicroRNA (MiRNA) is a small endogenous nonencoded RNA with a length of about 22 nucleotides that interacts with their corresponding target mRNAs to inhibit mRNA translation into proteins [49]. SNAI2 is also regulated by a variety of mRNAs. Shi et al. found that the inhibition of miR-218 contributes to the EMT and metastasis of lung cancer by targeting the SNAI2/ ZEB2 signaling pathway [15]. Interestingly, restoration of the expression of miR-200 downregulates SNAI2 and other inhibitory transcription factors, and reverses EMT in pancreatic cancer cells [36]. Results showed that miR-200b-3p, miR-30c-1-3P, and miR-363-3P targetedly bound to the $3^{\prime}$-UTR of SNAI2, downregulated SNAI2 expression, and inhibited the invasiveness of GIST cells, which further confirmed that miRNAs could inhibit GIST invasiveness through the SNAI2/ $\mathrm{CDH} 1$ axis. In the near future, miRNAs may become a novel drug target for cancer therapy. 

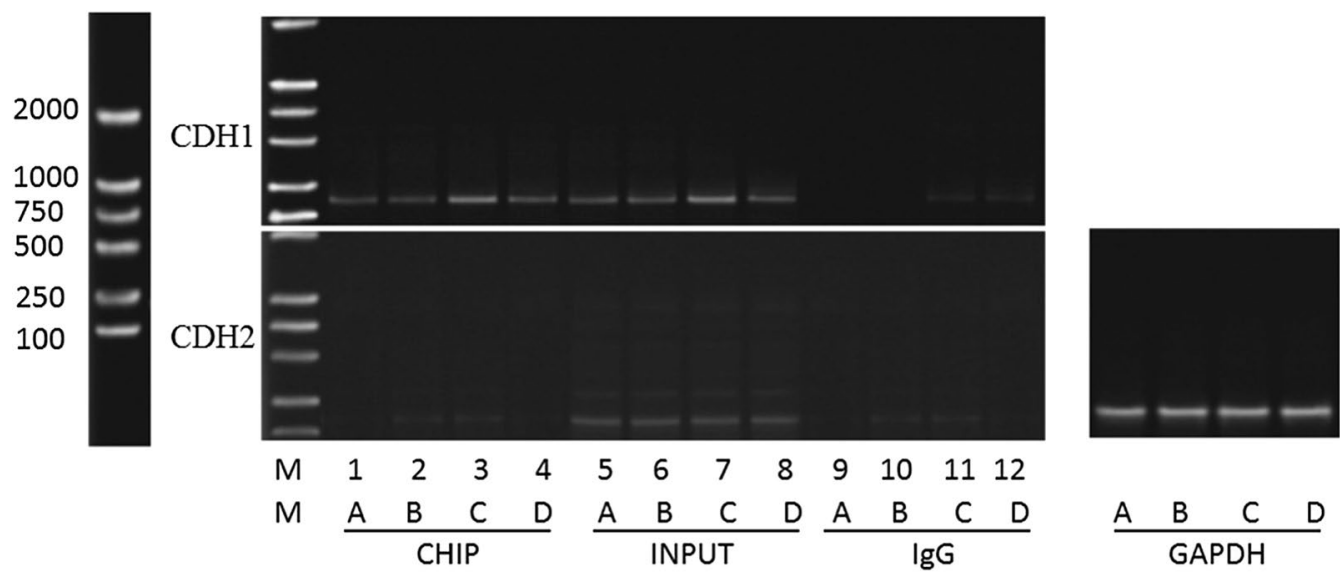
A: GIST
B: GIST+NC-siRNA
C: GIST+ cDNA
D: GIST+ siRNA

Fig. 10 ChIP assay in GIST cells. SNAI2 was present at the proximal promoter of $\mathrm{CDH}-1$, but not at the proximal promoter of CDH2, in GIST cells. Its level at the proximal promoter of $\mathrm{CDH}-1$ was significantly higher in SNAI2 overexpression group and lower in SNAI2 knockdown group

The present study has some limitations. First, aside from $\mathrm{CDH} 1$ and $\mathrm{CDH} 2$, other downstream metastasisassociated target genes of SNAI2 could be detected to illustrate the real situation of SNAI2-mediated metastasis of GISTs. Second, whether proteins such as LSD1 participate in the SNAI2-mediated metastasis of GISTs remain to be confirmed. Third, only two GIST cell lines were available, although we attempted to include more cell lines in this research. The effects of SNAI2 and their upstream miRNAs on the invasiveness of GIST cells might vary between different cell lines.

\section{Conclusion}

The results suggest that SNAI2 and CDH1 correlate with the metastasis of GISTs, and silencing of the SNAI2 gene impairs the invasiveness of GIST cells. MiR-200b-3p, miR-30c-1-3P, and miR-363-3P contribute to the metastasis of GISTs by mediating the SNAI2/ CDH1 axis. In the future, we will study their effects on the proliferation and metastasis of GISTs in vivo. SNAI2 may be a potential target for the treatment of GISTs (Additional files 1, 2).

\section{Supplementary information}

Supplementary information accompanies this paper at https://doi. org/10.1186/s12935-019-1006-8.

Additional file 1. Prediction of the upstream miRNAs of SNAI2 by Targetscan

Additional file 2. The microarray profiling of miRNAs in high-SNAI2-level GISTs and low-SNAI2-level GISTS

\section{Abbreviations}

GISTs: gastrointestinal stromal tumors; MiRNA: microRNA; CDH1: cadherin1; $\mathrm{CDH} 2$ : cadherin2; LSD1: lysine-specific demethylase 1; EMT: epithelial-mesenchymal transition.

\section{Acknowledgements}

The authors thank all the donors whose names were not included in the author list, but who contributed to our study.

\section{Authors' contributions}

$J D$ and $Y X$ designed and conducted the experiments, statistical analyses, data collection and drafted the manuscript. ZMZ and GQL supported with experimental techniques and guidance in statistical analyses. JW and ZXZ performed the immunohistochemical evaluation, ZYY collected clinical samples. $\mathrm{ZHL}, \mathrm{ZJ}$ and $\mathrm{HL}$ conducted the experiments. JD provided funds and acted as corresponding authors. All authors read and approved the final manuscript.

\section{Funding}

This study was supported by the National Natural Science Foundation of China (Nos. 81360366 and 81302169), the Science and Technology Fund of Guizhou Province (Nos. [2013]2178), Guizhou High-level Innovative Talents Foundation [No. GZSYQCC (2014)001], Guizhou Key Scientific and Technological Foundation (Nos. [2014]3023), Guizhou Outstanding Young Scientific and Technological Talents (Nos. [2017]5602), Guizhou Science and Technology Foundation (Nos. [2019]1198); Guizhou Innovation and Entrepreneurship Foundation for High-level Overseas Talent (Nos. [2018]04).

\section{Availability of data and materials}

All the literatures were collected by searching the PubMed and Web of Science database. The raw data and processed data of the study were available from the corresponding author upon reasonable request.

\section{Ethics approval and consent to participate}

This study was conducted with the approval of the ethics comittee of Guizhou Provincial People's Hospital, China, and the ethics comittee of of Xiangya hospital, Central South University. Documented informed consents were obtained from all patients.

\section{Consent for publication}

Not applicable. 


\section{Competing interests}

The authors declare that they have no competing interests.

\section{Author details}

${ }^{1}$ Department of Gastrointestinal Surgery, Guizhou Provincial People's Hospital, 83 East Zhongshan Rd, Guiyang 550002, Guizhou, China. ${ }^{2}$ Department of Stomatology, Guizhou Provincial People's Hospital, Guiyang 550002. China. ${ }^{3}$ Department of Pathology, Guizhou Provincial People's Hospital, Guiyang 550002, China. ${ }^{4}$ Department of Gastrointestinal Surgery, Xiangya Hospital, Central South University, Changsha 410008, China.

Received: 7 April 2019 Accepted: 29 October 2019

Published online: 12 November 2019

\section{References}

1. Joensuu H, Hohenberger P, Corless CL. Gastrointestinal stromal tumour. Lancet. 2013;382(9896):973-83. https://doi.org/10.1016/S0140 -6736(13)60106-3.

2. Hemming ML, Lawlor MA, Zeid R, Lesluyes T, Fletcher JA, Raut CP, Sicinska ET, Chibon F, Armstrong SA, Demetri GD, Bradner JE. Gastrointestinal stromal tumor enhancers support a transcription factor network predictive of clinical outcome. Proc Natl Acad Sci USA. 2018;115(25):E5746-55.

3. Joensuu $H$, Wardelmann E, Sihto H, Eriksson M, Sundby Hall K, Reichardt A, Hartmann JT, Pink D, Cameron S, Hohenberger P, Al-Batran SE, Schlemmer M, Bauer S, Nilsson B, Kallio R, Junnila J, Vehtari A, Reichardt P. Effect of KIT and PDGFRA mutations on survival in patients with gastrointestinal stromal tumors treated with adjuvant imatinib: an exploratory analysis of a randomized clinical trial. JAMA Oncol. 2017;3(5):602-9.

4. Mazur MT, Clark HB. Gastric stromal tumors: reappraisal of histogenesis. Am J Surg Pathol. 1983;7(6):507-19.

5. Ng EH, Pollock RE, Munsell MF, Atkinson EN, Romsdahl MM, Saluja H, Karapetis CS, Pedersen SK, Young GP, Symonds EL. The use of circulating tumor DNA for prognosis of gastrointestinal cancers. Front Oncol. 2018;8:275.

6. Joensuu H, Eriksson M, Sundby Hall K, Reichardt A, Hartmann JT, Pink D, Ramadori G, Hohenberger P, Al-Batran SE, Schlemmer M, Bauer S, Wardelmann E, Nilsson B, Sihto H, Bono P, Kallio R, Junnila J, Alvegård T, Reichardt P. Adjuvant imatinib for high-risk GI stromal tumor: analysis of a randomized trial. J Clin Oncol. 2016;34(3):244-50.

7. Cheng JC, Chang HM, Leung PC. Egr-1 mediates epidermal growth factor-induced downregulation of E-cadherin expression via Slug in human ovarian cancer cells. Oncogene. 2013;32(8):1041-9.

8. Tanaka Y, Terai Y, Kawaguchi H, Fujiwara S, Yoo S, Tsunetoh S, Takai M, Kanemura M, Tanabe A, Ohmichi M. Prognostic impact of EMT (epithelial-mesenchymal-transition)-related protein expression in endometrial cancer. Cancer Biol Ther. 2013;14(1):13-9.

9. Hajra KM, Chen DY, Fearon ER. The SLUG zinc-finger protein represses E-cadherin in breast cancer. Cancer Res. 2002;62(6):1613-8.

10. Kim S, Yao J, Suyama K, Qian X, Qian BZ, Bandyopadhyay S, Loudig O, De Leon-Rodriguez C, Zhou ZN, Segall J, Macian F, Norton L, Hazan RB. Slug promotes survival during metastasis through suppression of Pumamediated apoptosis. Cancer Res. 2014;74(14):3695-706.

11. Ding J, Liao GQ, Zhang ZM, Pan Y, Li DM, Chen HJ, Wang SY, Li Y, Wei N. Expression and significance of Slug, E-cadherin and N-cadherin in gastrointestinal stromal tumors. Zhonghua Yi Xue Za Zhi. 2012;92(4):264-8.

12. Park JJ, Park MH, Oh EH, Soung NK, Lee SJ, Jung JK, Lee OJ, Yun SJ, Kim WJ, Shin EY, Kim EG. The p21-activated kinase 4-Slug transcription factor axis promotes epithelial-mesenchymal transition and worsens prognosis in prostate cancer. Oncogene. 2018;37(38):5147-59.

13. Ye X, Tam WL, Shibue T, Kaygusuz Y, Reinhardt F, Ng Eaton E, Weinberg RA. Distinct EMT programs control normal mammary stem cells and tumourinitiating cells. Nature. 2015;525(7568):256-60.

14. Chen Y, Wang DD, Wu YP, Su D, Zhou TY, Gai RH, Fu YY, Zheng L, He QJ, Zhu H, Yang B. MDM2 promotes epithelial-mesenchymal transition and metastasis of ovarian cancer SKOV3 cells. Br J Cancer. 2017;117(8):1192-201.

15. Shi ZM, Wang L, Shen H, Jiang CF, Ge X, Li DM, Wen YY, Sun HR, Pan MH, Li W, Shu YQ, Liu LZ, Peiper SC, He J, Jiang BH. Downregulation of miR-218 contributes to epithelial-mesenchymal transition and tumor metastasis in lung cancer by targeting Slug/ZEB2 signaling. Oncogene. 2017;36(18):2577-88

16. Tang B, Qi G, Tang F, Yuan S, Wang Z, Liang X, Li B, Yu S, Liu J, Huang Q, Wei Y, Zhai R, Lei B, Yu H, Tomlinson S, He S. Aberrant JMJD3 expression upregulates slug to promote migration, invasion, and stem cell-like behaviors in hepatocellular carcinoma. Cancer Res. 2016;76(22):6520-32.

17. Ferrari-Amorotti G, Fragliasso V, Esteki R, Prudente Z, Soliera AR, Cattelani S, Manzotti G, Grisendi G, Dominici M, Pieraccioli M, Raschellà G, Chiodoni C, Colombo MP, Calabretta B. Inhibiting interactions of lysine demethylase LSD1 with snail/slug blocks cancer cell invasion. Cancer Res. 2013;73(1):235-45.

18. Cheng HL, Lin CW, Yang JS, Hsieh MJ, Yang SF, Lu KH. Zoledronate blocks geranylgeranylation not farnesylation to suppress human osteosarcoma U2OS cells metastasis by EMT via Rho A activation and FAK-inhibited JNK and p38 pathways. Oncotarget. 2016;7(9):9742-58.

19. Li G, Yang Y, Xu S, Ma L, He M, Zhang Z. Slug signaling is up-regulated by CCL21/CCR19 [corrected] to induce EMT in human chondrosarcoma. Med Oncol. 2015;32(2):478.

20. Li Y, Shao G, Zhang M, Zhu F, Zhao B, He C, Zhang Z. miR-124 represses the mesenchymal features and suppresses metastasis in Ewing sarcoma. Oncotarget. 2017:8(6):10274-86.

21. Yang J, Eddy JA, Pan Y, Hategan A, Tabus I, Wang Y, Cogdell D, Price ND, Pollock RE, Lazar AJ, Hunt KK, Trent JC, Zhang W. Integrated proteomics and genomics analysis reveals a novel mesenchymal to epithelial reverting transition in leiomyosarcoma through regulation of slug. Mol Cell Proteomics. 2010;9(11):2405-13.

22. Khan J, Bittner ML, Saal LH, Teichmann U, Azorsa DO, Gooden GC, Pavan WJ, Trent JM, Meltzer PS. CDNA microarrays detect activation of a myogenic transcription program by the PAX3-FKHR fusion oncogene. Proc Natl Acad Sci USA. 1999;96(23):13264-9.

23. Saito T, Nagai M, Ladanyi M. SYT-SSX1 and SYT-SSX2 interfere with repression of E-cadherin by snail and slug: a potential mechanism for aberrant mesenchymal to epithelial transition in human synovial sarcoma. Cancer Res. 2006;66(14):6919-27.

24. Guo Y, Xie J, Rubin E, Tang YX, Lin F, Zi X, Hoang BH. Frzb, a secreted Wnt antagonist, decreases growth and invasiveness of fibrosarcoma cells associated with inhibition of Met signaling. Cancer Res. 2008;68(9):3350-60.

25. Gasperini P, Espigol-Frigole G, McCormick PJ, Salvucci O, Maric D, Uldrick TS, Polizzotto MN, Yarchoan R, Tosato G. Kaposi sarcoma herpesvirus promotes endothelial-to-mesenchymal transition through Notchdependent signaling. Cancer Res. 2012;72(5):1157-69.

26. Sharma-Walia N, Patel K, Chandran K, Marginean A, Bottero V, Kerur N, Paul AG. COX-2/PGE2: molecular ambassadors of Kaposi's sarcoma-associated herpes virus oncoprotein-V-FLIP. Oncogenesis. 2012;1:e5.

27. Idda ML, Lodde V, McClusky WG, Martindale JL, Yang X, Munk R, Steri M, Orrù V, Mulas A, Cucca F, Abdelmohsen K, Gorospe M. Cooperative translational control of polymorphic BAFF by NF90 and miR-15a. Nucleic Acids Res. 2018;46(22):12040-51.

28. Hu S, Wang H, Kong X, Yan D, Lu W, Gao P, Lou W. Loss of miR-16 contributes to tumor progression by activation of tousled-like kinase 1 in oral squamous cell carcinoma. Cell Cycle. 2018;17(18):2284-95.

29. Chen X, Xiong D, Ye L, Wang K, Huang L, Mei S, Wu J, Chen S, Lai X, Zheng L, Wang M. Up-regulated IncRNA XIST contributes to progression of cervical cancer via regulating miR-140-5p and ORC1. Cancer Cell Int. 2019;19:45.

30. Ambros V. microRNAs: tiny regulators with great potential. Cell. 2001;107(7):823-6.

31. Zhu X, Wang X, Wei S, Chen Y, Chen Y, Fan X, Han S, Wu G. hsa_ circ_0013958: a circular RNA and potential novel biomarker for lung adenocarcinoma. FEBS J. 2017;284(14):2170-82.

32. White NM, Fatoohi E, Metias M, Jung K, Stephan C, Yousef GM. Metastamirs: a stepping stone towards improved cancer management. Nat Rev Clin Oncol. 2011;8(2):75-84

33. Pan Q, Meng L, Ye J, Wei X, Shang Y, Tian Y, He Y, Peng Z, Chen L, Chen W, Bian X, Wang R. Transcriptional repression of miR-200 family members by Nanog in colon cancer cells induces epithelial-mesenchymal transition (EMT). Cancer Lett. 2017;392:26-38.

34. Yu CC, Chen PN, Peng CY, Yu CH, Chou MY. Suppression of miR-204 enables oral squamous cell carcinomas to promote cancer stemness, EMT traits, and lymph node metastasis. Oncotarget. 2016;7(15):20180-92. 
35. Liu YN, Yin JJ, Abou-Kheir W, Hynes PG, Casey OM, Fang L, Yi M, Stephens RM, Seng V, Sheppard-Tillman H, Martin P, Kelly K. MiR-1 and miR-200 inhibit EMT via Slug-dependent and tumorigenesis via Slug-independent mechanisms. Oncogene. 2013;32(3):296-306.

36. Li Y, VandenBoom TG 2nd, Kong D, Wang Z, Ali S, Philip PA, Sarkar FH. Upregulation of miR-200 and let-7 by natural agents leads to the reversal of epithelial-to-mesenchymal transition in gemcitabine-resistant pancreatic cancer cells. Cancer Res. 2009;69(16):6704-12.

37. Joensuu H. Risk stratification of patients diagnosed with gastrointestinal stromal tumor. Hum Pathol. 2008;39(10):1411-9.

38. Tuveson DA, Willis NA, Jacks T, Griffin JD, Singer S, Fletcher CD, Fletcher JA, Demetri GD. STI571 inactivation of the gastrointestinal stromal tumor c-KIT oncoprotein: biological and clinical implications. Oncogene. 2001;20(36):5054-8.

39. Taguchi T, Sonobe H, Toyonaga S, Yamasaki I, Shuin T, Takano A, Araki K, Akimaru K, Yuri K. Conventional and molecular cytogenetic characterization of a new human cell line, GIST-T1, established from gastrointestinal stromal tumor. Lab Invest. 2002;82(5):663-5.

40. Kahl P, Gullotti L, Heukamp LC, Wolf S, Friedrichs N, Vorreuther R, Solleder G, Bastian PJ, Ellinger J, Metzger E, Schüle R, Buettner R. Androgen receptor coactivators lysine-specific histone demethylase 1 and four and a half LIM domain protein 2 predict risk of prostate cancer recurrence. Cancer Res. 2006;66(23):11341-7.

41. Pruitt K, Zinn RL, Ohm JE, McGarvey KM, Kang SH, Watkins DN, Herman JG, Baylin SB. Inhibition of SIRT1 reactivates silenced cancer genes without loss of promoter DNA hypermethylation. PLoS Genet. 2006;2(3):e40.

42. Polyak K, Weinberg RA. Transitions between epithelial and mesenchymal states: acquisition of malignant and stem cell traits. Nat Rev Cancer. 2009;9(4):265-73.

43. Brabletz T. EMT and MET in metastasis: where are the cancer stem cells? Cancer Cell. 2012;22(6):699-701.
44. Pulkka OP, Nilsson B, Sarlomo-Rikala M, Reichardt P, Eriksson M, Hall KS, Wardelmann E, Vehtari A, Joensuu H, Sihto H. SLUG transcription factor: a pro-survival and prognostic factor in gastrointestinal stromal tumour. Br J Cancer. 2017;116(9):1195-202.

45. Bolós V, Peinado H, Pérez-Moreno MA, Fraga MF, Esteller M, Cano A. The transcription factor Slug represses E-cadherin expression and induces epithelial to mesenchymal transitions: a comparison with Snail and E47 repressors. J Cell Sci. 2003;1 16(Pt 3):499-511.

46. Ferrari-Amorotti G, Chiodoni C, Shen F, Cattelani S, Soliera AR, Manzotti G, Grisendi G, Dominici M, Rivasi F, Colombo MP, Fatatis A, Calabretta B. Suppression of invasion and metastasis of triple-negative breast cancer lines by pharmacological or genetic inhibition of slug activity. Neoplasia. 2014;16(12):1047-58.

47. Lin Y, Wu Y, Li J, Dong C, Ye X, Chi YI, Evers BM, Zhou BP. The SNAG domain of Snail 1 functions as a molecular hook for recruiting lysine-specific demethylase 1. EMBO J. 2010;29:1803-16.

48. Bai JW, Chen MN, Wei XL, Li YC, Lin HY, Chen M, Li JW, Du CW, Man K, Zhang GJ. The zinc-finger transcriptional factor Slug transcriptionally downregulates ERa by recruiting lysine-specific demethylase 1 in human breast cancer. Oncogenesis. 2017;6(5):e330.

49. Lv Y, Yang H, Ma X, Wu G. Strand-specific miR-28-3p and miR-28-5p have differential effects on nasopharyngeal cancer cells proliferation, apoptosis, migration and invasion. Cancer Cell Int. 2019;19:187.

\section{Publisher's Note}

Springer Nature remains neutral with regard to jurisdictional claims in published maps and institutional affiliations.
Ready to submit your research? Choose BMC and benefit from:

- fast, convenient online submission

- thorough peer review by experienced researchers in your field

- rapid publication on acceptance

- support for research data, including large and complex data types

- gold Open Access which fosters wider collaboration and increased citations

- maximum visibility for your research: over $100 \mathrm{M}$ website views per year

At BMC, research is always in progress.

Learn more biomedcentral.com/submissions 